Haya: The Saudi Journal of Life Sciences

Abbreviated Key Title: Haya Saudi J Life Sci ISSN 2415-623X (Print) |ISSN 2415-6221 (Online) Scholars Middle East Publishers, Dubai, United Arab Emirates Journal homepage: http://scholarsmepub.com/haya/

Original Research Article

\title{
Effect of Salicylic Acid Sprays on the Performance of Fenugreek Grown with Graded Levels of Salinity
}

\author{
Firoz Mohammad $^{1 *}$, Mir Abdul Wajid ${ }^{2}$ and Mansoor Ahmad Bhat ${ }^{3}$
}

${ }^{1}$ Professor, Department of Botany, Aligarh Muslim University, Aligarh, Uttar Pradesh 202001, India

${ }^{2}$ Department of Botany, Aligarh Muslim University, Aligarh, Uttar Pradesh 202001, India

${ }^{3}$ Department of Environmental Engineering, Eskişehir Teknik Üniversitesi, 2 Eylül Kampüsü, 26555 Tepebaşı/Eskişehir, Turkey

DOI: $10.36348 /$ SJLS.2019.v04i10.003 $\quad$ | Received: 07.11.2019| Accepted: 20.11.2019| Published: 26.11 .2019

*Corresponding author: Mansoor Ahmad Bhat

Abstract

An experiment was carried out in a net-house, Aligarh Muslim University Department of Botany. The six different treatments that were used in this study includes control, Salicylic acid, $\mathrm{NaCl}(50 \mathrm{mM}), \mathrm{SA}+50 \mathrm{mM} \mathrm{NaCl}, 100 \mathrm{mM} \mathrm{NaCl}$ and $\mathrm{SA}+100 \mathrm{mM} \mathrm{NaCl}$. The resultant plants from salt-treated seeds of the present investigation indicated that seeds recorded lower values for all the growth attributing parameters. It was deep-rooted that $50 \mathrm{mM}$ and $100 \mathrm{mM}$ salt concentrations harm the growth, biochemical and yield parameters of fenugreek. Salt stress reduces plant height, fresh weight, dry weight, chlorophyll content, Nitrate reductase activity, number of pods and seed yield in fenugreek. The foliar application of Salicylic acid alleviates the negative effect of salinity. This effect was more pronounced in $50 \mathrm{mM}$ salt stress than $100 \mathrm{mM}$.

Keywords: Salicylic acid, Fenugreek, Sodium chloride, Chlorophyll, Vegetative growth, Biochemical parameter's, Nitrate reductase activity, Morphology and Salt stress.

Copyright @ 2019: This is an open-access article distributed under the terms of the Creative Commons Attribution license which permits unrestricted use, distribution, and reproduction in any medium for non-commercial use (NonCommercial, or CC-BY-NC) provided the original author and source are credited.

\section{INTRODUCTION}

Medicinal plants are used as natural remedies. This practice has existed since primitive times. There are different ways in which plants have been found beneficial in medicinally. First, they may be used straight as teas or in other extracted forms for their natural chemical constituents. Second, they may be used as healing agents in the synthesis of medicines. Finally, the organic compounds found in plants may be used as representations for synthetic medication. Plants are directly used as medicines by some countries around the world, e.g. China, India, Pakistan, Bangladesh, etc. Numerous food crops (e.g. garlic, turmeric, fennel, etc.) have curative properties. The therapeutic properties of plants are due to the secondary compounds produced by a few plant classes. Plant metabolites include primary metabolites and secondary metabolites. It is assessed that about 70,000 plant species, from lichens to towering trees, have been used, at one time or another for therapeutic purposes. The herbs provide the starting material for isolation or synthesis of conventional medications. In Ayurveda, around 2,000 plant species are measured to have medicinal values, whereas the Chinese pharmacopoeia lists over 5,700 traditional drugs, most of which are of plant origin. Medicinal plants have healing properties due to the presence of various complex chemical substances of different composition, which are the secondary plant metabolites produced by these plants. These plant metabolites, according to their form, are grouped as alkaloids, glycosides, corticosteroids, essential oils, etc. An estimate of the EXIM Bank sets the global market of medicinal plants associated trade at US $\$ 60$ billion per year, increasing at the percentage of $7 \%$ only. However, India has rich biodiversity; the growing demand is putting a heavy straining on the remaining resources. Whereas the demand for medicinal plants is increasing, some of them are gradually being threatened in their natural environment. For meeting the future needs, farming of medicinal plant must be encouraged.

Trigonella foenum-graecum L. (fenugreek) is an annual herb of family Fabaceae and is a native to Southern Europe, the Mediterranean area and Western Asia. Fenugreek is locally recognised as Methi and is cultivated throughout the country for culinary and remedial determinations; it is also grownup as food. This plant is well-identified for its miraculous curative properties, viz. anti-diabetic, anti-cholesterol, anti- 
malarial, antioxidant, anti-cancerous, cures anaemia and respiratory disorders, relieves skin irritation, used in the treatment of indigestion and flatulence, used as a galactagogue and as an immunomodulatory agent. Medicinal properties of fenugreek can be attributed to its bioactive constituents like 4-hydroxy isoleucine (4$\mathrm{HI}$ ), trigonelline, galactomannans, diosgenin, flavonoids, carotenoids, coumarins, proteins, saponins and fats. Fenugreek seeds act as a dietary supplement and significantly reduces the symptoms of DM like polydipsia, polyuria, urine sugar, renal hypertrophy and glomerular filtration rate [1]. Fenugreek seed-alkaloid, known as trigonelline (Fig-1) controls diabetes mellitus through the operation of the mechanism of insulin secretion, modulation of $\beta$ cell regeneration and stimulation of the activity of glucose metabolismrelated enzymes [2, 3]. However, like most of the cultivated plants, growth and yield of these plants can be affected by environmental constraints such as soil and water salinity. Predictably, salt stress would cause an imbalance of the cellular ions resulting in ion toxicity and osmotic stress [4], thus affecting the plant growth, morphology and survival [5]. The salt effects on florae can be notable, the initial one is an osmotic effect, and it is due to a reduction in rhizosphere osmotic potential, which makes water uptake problematic [6]. The other is the toxic effect resulting from the capability of sodium to compete with $\mathrm{K}^{+}$, for binding sites necessary for cell function. Lastly a nutritional impact due to the limitation of nutrient uptake and transport [6] by antagonism between $\mathrm{Na}^{+}$ and essential cations on the one hand and between $\mathrm{Cl}^{-}$ and essential anions on the other hand [7].

Salinity generates oxidative stress in plant tissues, which is manifested by reactive oxygen species (ROS) such as singlet oxygen, superoxide anion, hydrogen peroxide and hydroxyl radical [8] Plants have advanced various protective mechanisms to eliminate or reduce ROS. Free extreme reactions, especially with the participation of oxidative radicals, are involved in many biological processes that cause damage to lipids, proteins, membranes and nucleic acids, thus giving rise to a variety of diseases [9]. The plant stress response involves the synthesis of several secondary metabolites of the phenylpropanoid pathway, such as a nonenzymatic system to defend the plant. Moreover, it has been strong-minded that the antioxidant effect of plant products is mainly due to phenolic complexes, such as flavonoids, phenolic acids, tannins and phenolic diterpenes [10]. Phenolic compounds play an essential role in absorbing and neutralising free radicals, quenching singlet oxygen, or decomposing peroxide [11]. Salicylic acid (SA) is a phenolic compound (Fig. 1) which, despite its broad distribution in plants, has basal levels differing widely among species, with up to 100-fold differences having been documented [12]. SA or ortho-hydroxybenzoic acid is a phenolic compound synthesised throughout the plant kingdom via the phenylpropanoid pathway [13]. SA has been recognized as a regulatory signal mediating plant response to abiotic stresses such as drought [14], chilling $[15,13]$, substantial metal tolerance $[16,17]$ heat and osmotic stress [18]. Salicylic acid (SA) acts as a signalling molecule and is involved in the expression of specific responses in plants to stresses mentioned above in addition to salt stress.

Additionally, SA acts as a potential nonenzymatic antioxidant as well as a plant growth regulator, which plays an essential role in regulating several plant physiological processes including photosynthesis [19-21]. An effect of exogenous SA on photosynthesis is concentration-dependent [22]. At low concentrations (less than $10 \mu \mathrm{M}$ ), SA is known to alleviate a salt-induced decrease in photosynthesis by increasing photosynthetic rate [23, 24] carbon fixation, transpiration, stomatal conductance [23] and antioxidant activity [25] in many plant species.

Some studies suggested maintenance of optimum $\mathrm{K}^{+} / \mathrm{Na}^{+}$ratio under saline conditions as a reason for enhanced salt tolerance in plants (reviewed in [25-27]. Usually, exogenous SA minimises $\mathrm{Na}+$ uptake while increasing tissue concentrations of $\mathrm{K}^{+}$, $\mathrm{Ca}^{+}, \mathrm{Mg}^{2+}[28,29], \mathrm{Fe}^{2+}, \mathrm{Mn}^{2+}, \mathrm{Cu}^{2+}[30,24]$ in many plant species. SA could contribute to maintaining cellular redox homeostasis through the regulation of antioxidant enzymes activity [31, 32] and induction of the alternative respiratory pathway [33] and to regulating gene expression by inducing an RNA dependent RNA polymerase that is important for posttranscriptional gene silencing. These observations suggest that SA being an oxidant could be linked to oxidative stress.

\section{General Description}

Trigonella foenum-graecum L. commonly identified as Fenugreek is an annual herb of family Fabaceae (Figure-1). It was named, Trigonella, from the Latin language that means 'little triangle' due to its yellowish-white triangular flowers. Fenugreek is one of the primitive medicinal plants from the Fabaceae family originated in central Asia $4000 \mathrm{BC}$ [34]. It is cultured in North Africa, Pakistan, China, India, Egypt and the Mediterranean countries. In India, Fenugreek is mostly cultivated in the states of Madhya Pradesh, Uttar Pradesh, Rajasthan, Gujarat, Maharashtra and Punjab. Fenugreek is an annual dicotyledonous plant attaining a height of about $20-130 \mathrm{~cm}$. The stem is smooth, green to purple and is often characterised by pinkish colour due to anthocyanin accumulation under field condition. It has a well-developed taproot with extended fibrous roots. Leaves are light green, pinnate and arranged alternately with three ovate leaflets. Flowers are 1-2, axillary in position and may be white or yellow. The inflorescence is compound umbel, terminal. Pods are 3 $15 \mathrm{~cm}$ long with persistent beak, with each pod having $10-20$ seeds. Seeds are dull yellow to brownish-yellow in colour, $2.5-5 \times 2-3.5 \mathrm{~mm}$ in size, rectangular and carry 
a deep groove, giving the seeds a hooked appearance. Fenugreek is propagated by seeds $[34,35]$. The seed of fenugreek is a rich source of fibre, which is mainly comprised of galactomannans [36], polyphenolic compounds [24]. The chemical constituents of $\mathrm{T}$. foenum-graecum include flavonoids, saponins, polysaccharides, and alkaloids like trigonelline and choline [33].

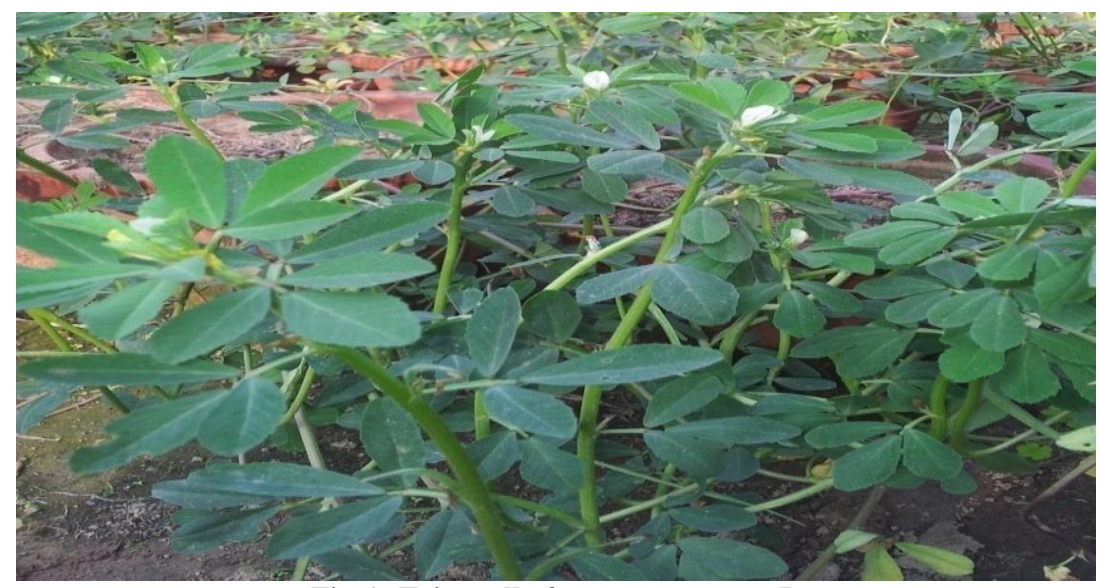

Fig-1: Trigonella foenum-graecum $\mathrm{L}$

Systematic position

Kingdom: Plantae

Division: Magnoliophyta

Class: Magnoliopsida

Order: Fabales

Family - Fabaceae

Sub-family - Papilionaceae

Genus - Trigonella

Species - Foenum-graecum Linn.

\section{Uses of Trigonella foenum-graecum}

Fenugreek possesses pharmacological properties such as anti-diabetic, anti-parasitic, carminative laxative, anti-carcinogenic, antiviral, antioxidant, anti-inflammatory anti-microbial and anticholesterolemic [28, 35]. Fenugreek is one such plant that has been extensively used in different systems of medicine as a source of antidiabetic compounds obtained from its seeds, leaves and extracts. Besides, it regulates several enzymatic activities, relieves fever, reduces body pain and fat, alleviates swelling, augments appetite and promotes lactation and sex hormones. Both ripened and unripened seeds, as well as green leaves, have been used as a vegetable, food additive, medicinal plant and fodder in South and Central Asian countries [33]. However, it is well known as a flavour, curry powder and spice, and has also been used in tea and as a food preservative in sauces and pickles. Fenugreek is also being used in the paper industry, cosmetics, pharmacology, beverages, perfume, paints and some of the food-oriented implications. Fenugreek is also used as a rotation crop; it increases nitrogen fixation in the soil and is used as a livestock feed [37].

\section{Salicylic acid}

It is known as 2-hydroxybenzoic acid and is one of the diverse groups of phenolic compounds. In the year 1828, Buchner isolated salicyl alcohol glucoside (salicin) from willow bark that was later named as salicylic acid by Piria in the year 1838 [45].<smiles>O=C(O)c1ccccc1O</smiles>

Fig-2: Salicylic acid

It plays an exclusive role in plant growth, thermogenesis, flower induction and uptake of ions. It affects ethylene biosynthesis, stomatal movement. It also enhances the level of photosynthetic pigment, photosynthetic rate and modifies some of the essential enzymes as well [27].

\section{MATERIALS AND METHODS}

To achieve the aims and objectives of the study, a randomised design pot experiment was conducted on Fenugreek (Trigonella foenum graceum). During 'rabi' (winter) season of (2016-2017) in a nethouse of the Department of Botany, Aligarh Muslim University, Aligarh. The principal objective of this experiment was to find out the effect of SA on growth, physiological and biochemical parameters and yield characteristics of fenugreek grown under salt stress. The details of ago-climatic conditions, soil analysis of the soil of experimental pots and the techniques and procedures employed are given below.

\section{Agro-Climatic Conditions}

Aligarh, an industrial area and a small university town of western Uttar Pradesh (North India), is located $130 \mathrm{~km}$ East of Delhi at $27^{\circ} 52^{\prime} \mathrm{N}$ latitude, $78^{\circ} 51^{\prime} \mathrm{E}$ longitude and $187.45 \mathrm{~m}$ altitude. It has a semiarid and subtropical climate with hot, dry summers and cold winters. During summer the average temperature recorded is $30.5^{\circ} \mathrm{C}$. May and June stand the hottest and driest months, during which the highest temperature has been documented to reach $45.5^{\circ} \mathrm{C}$. The wintertime 
extends from the middle of October to the end of March. The mean temperature for winter is $19^{\circ} \mathrm{C}$; the extreme minimum temperature record is $0.5^{\circ} \mathrm{C}$. At the end of June, the rainy season (monsoon) starts. The average yearly rainfall is about $847.3 \mathrm{~mm}$. More than 85 per cent of the total downpour is delivered during the rainy season (June-Sept).

\section{Filling of pots and Seeds}

Before transplanting, $4 \mathrm{~kg}$ homogenous mixture of soil and cow dung compost in the ratio of 4:1 was filled in the clay pots of $25 \mathrm{~cm}$ size. The soil was maintained at appropriate moisture to ensure better growth of the plants. The seeds of fenugreek were obtained from Chola Beej Bhandar, Aligarh India. They were surface sterilised with $0.01 \% \mathrm{HgCl}_{2}$, followed by repeated washing with distilled water.

\section{Pot experiment and Determinations}

The research was conducted on fenugreek during Rabi (winter) season of 2016-17. The pots were kept under natural day/night conditions. Five healthy seedlings of uniform size were maintained in each jar. The saline treatment and foliar application of SA were given after ten days of sowing. After 40 days in the experiment, the determination was made for various parameters. The investigation was conducted according to a simple randomised design. There were three replicates for each treatment. The plants were set aside free from weeds and watered when required. At 40 DAS, plants from each plot were taken with intact roots and washed with running tap water to wipe of adhering foreign particles and brought to the laboratory for growth, physiological and biochemical analysis. the salt treatment was given at the seedling stage via roots...

The following parameters were studied:

\section{Growth Parameters}

Shoot length plant $^{-1}$, Root length plant ${ }^{-1}$, Branch number plant ${ }^{-1}$, Leaf number plant $^{-1}$, Fresh weight of shoot plant $^{-1}$, Fresh weight of root plant ${ }^{-1}$, Dry weight of shoot plant ${ }^{-1}$, Dry weight of root plant ${ }^{-1}$ and Leaf area plant ${ }^{-1}$.

\section{Physiological and biochemical parameters}

Chlorophyll a content, Chlorophyll b content and Nitrate reductase activity

\section{Yield Characteristics}

Yield characteristics include a no. of pods per plant and number of seeds per pod.

\section{a) Shoot length, root length and leaf area.}

Plants were uprooted, washed and dried on blotting paper. Shoot length and root length of each plant were measured with the help of the meter scale. Leaf area was measured employing a graph paper method.

\section{b) The fresh and dry weight of shoot and root}

The plants were uprooted and cleaned under running tap water. The samples were weighed to obtain pure mass with the help of electronic balance. Shoot and root of each plant were dried separately in a hot air oven at $80^{\circ} \mathrm{C}$ for $24 \mathrm{~h}$. Dry weight was determined with the help of an electronic balance.

\section{Estimation of chlorophyll content}

Chlorophyll content (total chlorophyll) was estimated in fresh leaves. The chlorophyll content in leaves was assessed by the method of [44] $100 \mathrm{mg}$ new tissue from interveinal areas of leaves was ground using mortar and pestle in $10 \mathrm{~mL}$ of $80 \%$ acetone (Appendix). The suspension was sieved through Whatman filter paper No.1, and the filtrate was collected in a $100 \mathrm{ml}$ volumetric flask. Optical density (O.D.) was read at 645 and $663 \mathrm{~nm}$ using a spectrophotometer (Spectronic 20D, Milton and Roy, USA). A blank was run with each set of determination.

$$
\mathrm{Chl} \mathrm{a}=\frac{(12.7 \mathrm{~A} 663)-(2.63 \mathrm{~A} 645)}{\text { Weight }(\mathrm{g})} \times 1000
$$

$$
\mathrm{Chl} \mathrm{b}=\frac{(22.9 \mathrm{~A} 645)-(4.48 \mathrm{~A} 663)}{\text { Weight }(\mathrm{g})} \times 1000
$$

Total chlorophyll $=20.2 \times($ A. 645$)+8.02($ A. 663$) \mathrm{mg} \mathrm{g}-1 \mathrm{FW}$

\section{Nitrate reductase activity}

The activity of nitrate reductase (NR) in fresh leaves was estimated by the method of [39]. The plant leaves were cut into small pieces $\left(1 \mathrm{~cm}^{2}\right) .200 \mathrm{mg}$ of these chopped leaves were weighed and transferred to plastic bottles. To each bottle, $2.5 \mathrm{~mL}$ of phosphate buffer pH 7.5 (Appendix) and $0.5 \mathrm{~mL}$ of potassium nitrate solution (Appendix) was added followed by the addition of $2.5 \mathrm{~mL}$ of $5 \%$ isopropanol (Appendix). These bottles were incubated in a BOD incubator for 2 $\mathrm{h}$ at $30+2^{\circ} \mathrm{C}$ in the dark. $0.4 \mathrm{~mL}$ incubated mixture was taken in a test tube to which $0.3 \mathrm{~mL}$ each of sulphanilamide solution (Appendix) and N-1 Nepthyl ethylene diamine dihydrochloride (NED-HCl) (Appendix) were added. The test tubes were left for 20 minutes, for maximum colour development. The mixture was diluted to $5 \mathrm{~mL}$ double distilled water (DDW). The O.D. was read at $540 \mathrm{~nm}$ using the spectrophotometer. An absolute was run simultaneously with each sample. A standard curve was plotted by using a known graded concentration of sodium nitrite $\left(\mathrm{NaNO}_{2}\right)$ solution. The absorbance (O.D.) of each sample was compared with that of the calibration curve, and NR activity expressed at $\mu \mathrm{M} \mathrm{NO}_{2}^{-} \mathrm{g}^{-1}$ F.W. $\mathrm{h}^{-1}$.

\section{Statistical Analysis}

The investigational data were statistically analysed using the analyses of variance techniques according to [40]. When ' $F$ ' value was seen to be significant at the $5 \%$ level of probability, the standard error (SE) was calculated.

\section{RESULTS AND DISCUSSIONS}




\section{Shoot and Root length plant $^{-1}$}

The maximum shoot length was observed with the foliar spray of SA on plants grown without salt stress. The foliar application of SA alleviated the effects of salt stress, particularly at $50 \mathrm{mM} \mathrm{NaCl}$. Use of SA gave a higher value of 79.42 than the $100 \mathrm{mM} \mathrm{NaCl}$ (least value). The maximum root length was registered with the foliar spray of SA on plants grown without salt stress. The foliar application of SA alleviated the effects of salt stress, particularly at $50 \mathrm{mM} \mathrm{NaCl}$. Use of SA gave a higher value of $82.2 \%$ than the $100 \mathrm{mM} \mathrm{NaCl}$ (least value).

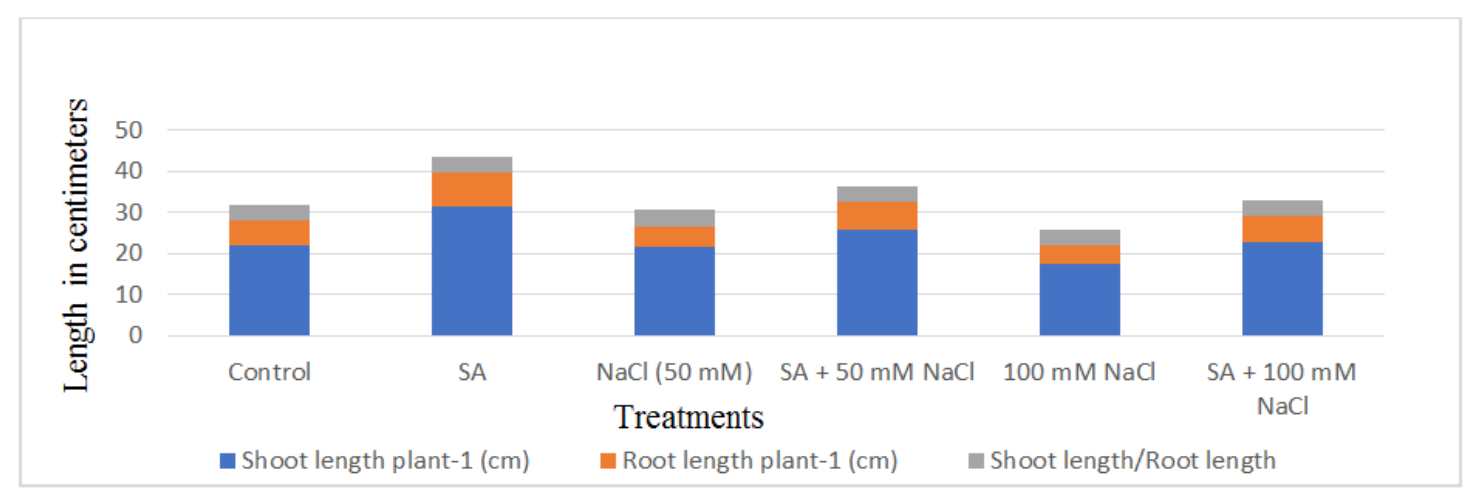

Graph-1: Effect of salicylic acid spray on shoot and root length of fenugreek grown with graded levels of salinity

\section{Number of branches and leaves plant ${ }^{-1}$}

The maximum number of branches was analyzed with the foliar spray of SA on plants grown without salt stress. The foliar application of SA alleviated the effects of salt stress, particularly at 50 $\mathrm{mM} \mathrm{NaCl}$. Use of SA gave a higher value of $100 \%$ than the $100 \mathrm{mM} \mathrm{NaCl}$ (least value). The maximum number of leaves was observed with the foliar spray of SA on plants grown without salt stress. The foliar application of SA alleviated the effects of salt stress, particularly at
$50 \mathrm{mM} \mathrm{NaCl}$. Form of $\mathrm{SA}$ gave a higher value of $44.44 \%$ than the $100 \mathrm{mM} \mathrm{NaCl}$ (least value).

\section{Leaf area plant ${ }^{-1}$}

The maximum leaf area was registered with the foliar spray of SA on plants grown without salt stress. The foliar application of SA alleviated the effects of salt stress, particularly at $50 \mathrm{mM} \mathrm{NaCl}$. Use of SA gave a higher value of $64.21 \%$ than the $100 \mathrm{mM} \mathrm{NaCl}$ (least value).

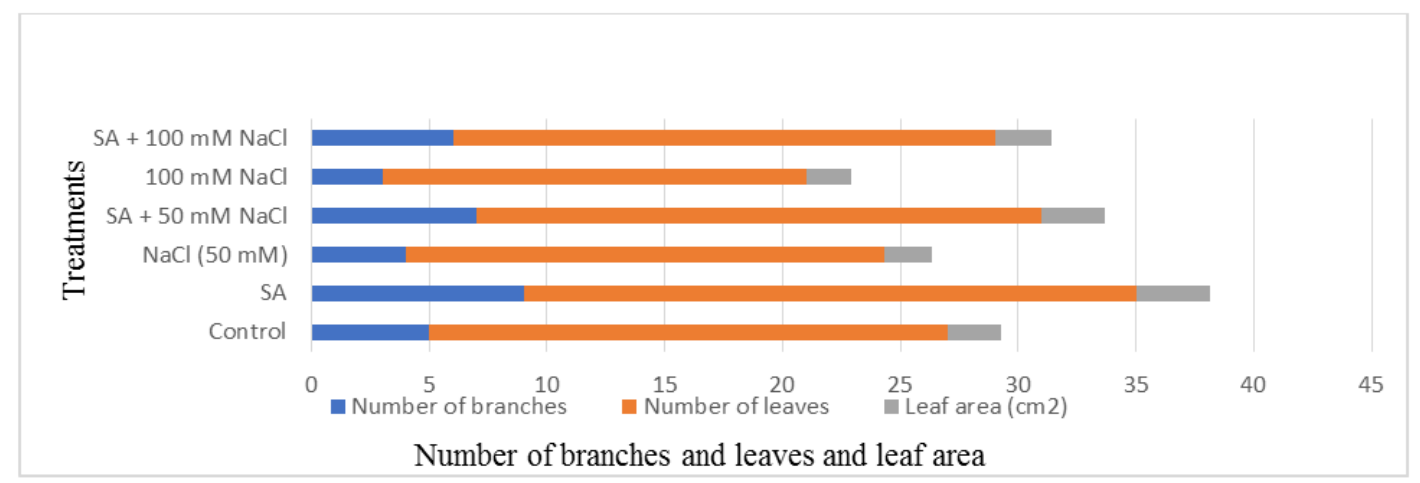

Graph-2: Effect of salicylic acid spray on number of leaves and branches and leaf area of fenugreek grown with graded levels of salinity

\section{Fresh and dry weight Shoot and Root plant ${ }^{-1}$}

The maximum shoot fresh weight was registered with the foliar spray of SA on plants grown without salt stress. The foliar application of SA alleviated the effects of salt stress, particularly at 50 $\mathrm{mM} \mathrm{NaCl}$. Use of SA gave a higher value of $83.67 \%$ than the $100 \mathrm{mM} \mathrm{NaCl}$ (least value). The maximum root fresh weight was observed with the foliar spray of SA on plants grown without salt stress. The foliar application of SA alleviated the effects of salt stress particularly at $50 \mathrm{mM} \mathrm{NaCl}$. Use of SA gave a higher value of $90.47 \%$ than the $100 \mathrm{mM} \mathrm{NaCl}$ (least value).
The maximum shoot dry weight was reported with the foliar spray of SA on plants grown without salt stress. The foliar application of SA alleviated the effects of salt stress, particularly at $50 \mathrm{mM} \mathrm{NaCl}$. Use of SA gave higher value $111.9 \%$ than the $100 \mathrm{mM} \mathrm{NaCl}$ (least value). The maximum root dry weight was analyzed with the foliar spray of SA on plants grown without salt stress. The foliar application of SA alleviated the effects of salt stress, particularly at $50 \mathrm{mM} \mathrm{NaCl}$. Use of SA gave a higher value of $100 \%$ than the $100 \mathrm{mM} \mathrm{NaCl}$ (least value). 


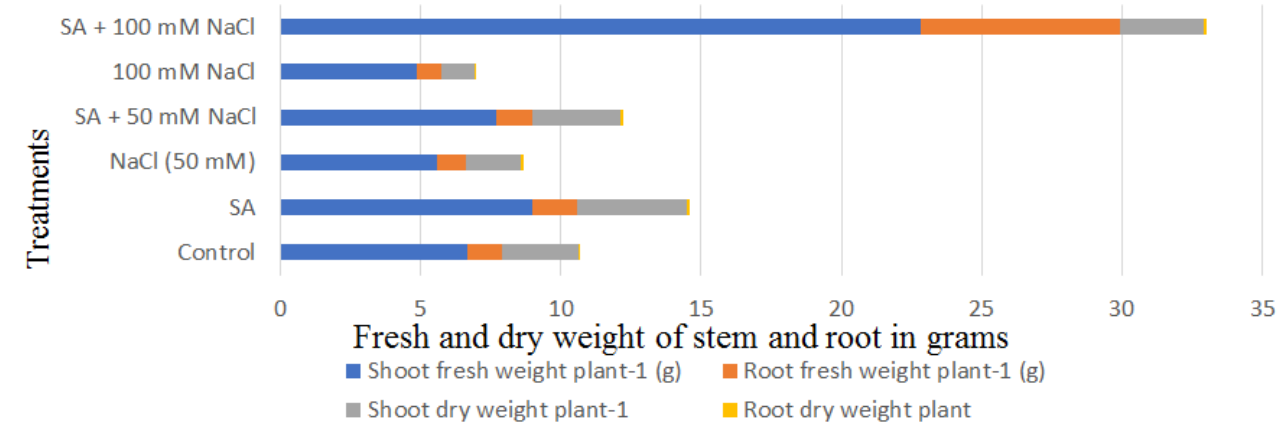

Graph-3: Effect of salicylic acid spray on fresh and dry weight of shoot and root of fenugreek grownwith graded levels of salinity

\section{Chlorophyll a and Chlorophyll b content plant ${ }^{-1}$}

The maximum chlorophyll content was observed with the foliar spray of SA on plants grown without salt stress. The foliar application of SA alleviated the effects of salt stress, particularly at 50 $\mathrm{mM} \mathrm{NaCl}$. Use of SA gave higher value $71.42 \%$ than the $100 \mathrm{mM} \mathrm{NaCl}$ (least value). The maximum chlorophyll b content was observed with the foliar spray of SA on plants grown without salt stress. The foliar application of SA alleviated the effects of salt stress, particularly at $50 \mathrm{mM} \mathrm{NaCl}$. Use of SA gave a higher value of $266.66 \%$ than the $100 \mathrm{mM} \mathrm{NaCl}$ (least value).

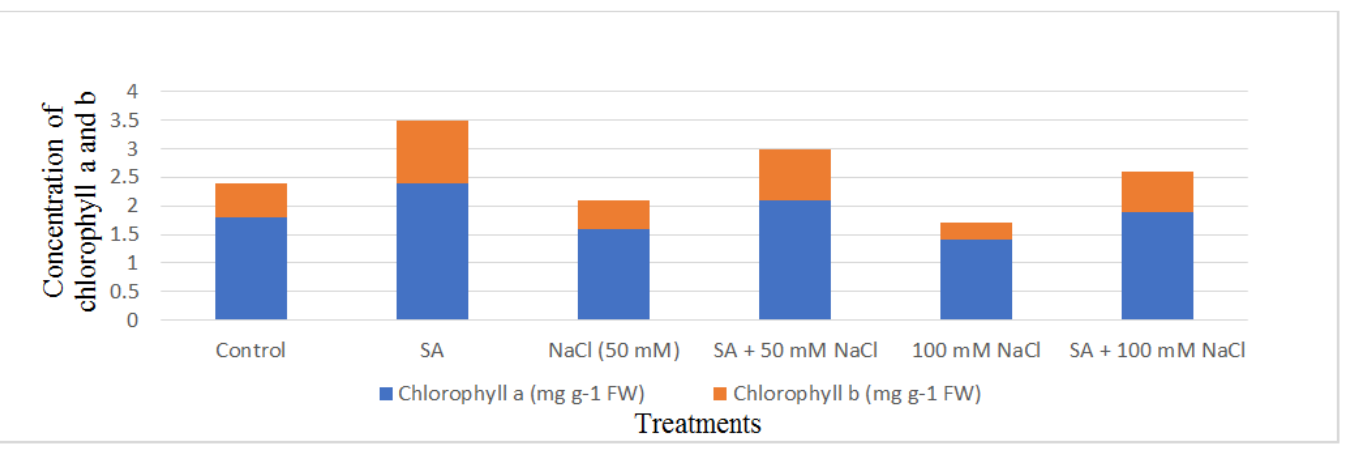

Graph-4: Effect of salicylic acid spray on Chlorophyll a and Chlorophyll b of fenugreek grown with graded levels of salinity

\section{NR activity plant ${ }^{-1}\left(\mu \mathrm{M} \mathrm{NO}{ }_{2}^{-1} \mathrm{~g}^{-1} \mathrm{FWh}^{-1}\right)$.}

The maximum NR activity was registered with the foliar spray of SA on plants grown without salt stress. The foliar application of SA alleviated the effects of salt stress, particularly at $50 \mathrm{mM} \mathrm{NaCl}$. Form of SA gave a higher value of $52.02 \%$ than the $100 \mathrm{mM} \mathrm{NaCl}$ (least value).

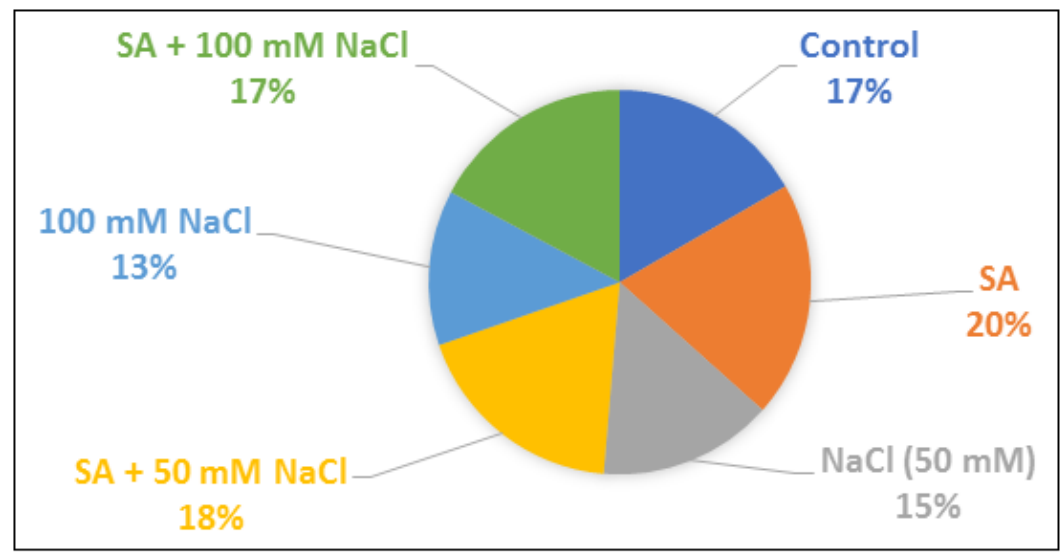

Graph-5: Effect of salicylic acid spray on nitrate reductase activity of fenugreek grown with graded levels of salinity 


\section{Number of pods plant $^{-1}$ and Number of seeds per pod}

The maximum number of pods was registered with the foliar spray of SA on plants grown without salt stress. The foliar application of SA alleviated the effects of salt stress, particularly at $50 \mathrm{mM} \mathrm{NaCl}$. Application of SA gave a higher value of $50 \%$ than the $100 \mathrm{mM}$ $\mathrm{NaCl}$ (least value). The maximum number of seeds per pod was registered with the foliar spray of SA on plants grown without salt stress. The foliar application of SA alleviated the effects of salt stress, particularly at 50 $\mathrm{mM} \mathrm{NaCl}$. Application of SA gave a higher value of
$142.85 \%$ than the $100 \mathrm{mM} \mathrm{NaCl}$ (least value). In modern times the industrialisation and the use of various fertilisers and salts to enhance the productivity of plants has led to the degradation of soils. The degradation of the soils mainly occurs due to the accumulation of the sodium chloride in them, which is also referred to as salinisation. At present, about $7 \%$ of the world's total land is affected by salinity. Australia $38 \%$, South America 14\%, Africa 8.4\%, North America $1.7 \%$, Central America $0.5 \%$ and $5.4 \%$. Other estimates also show $50 \%$ of total land affected by the salinity (Adam and Hughes).

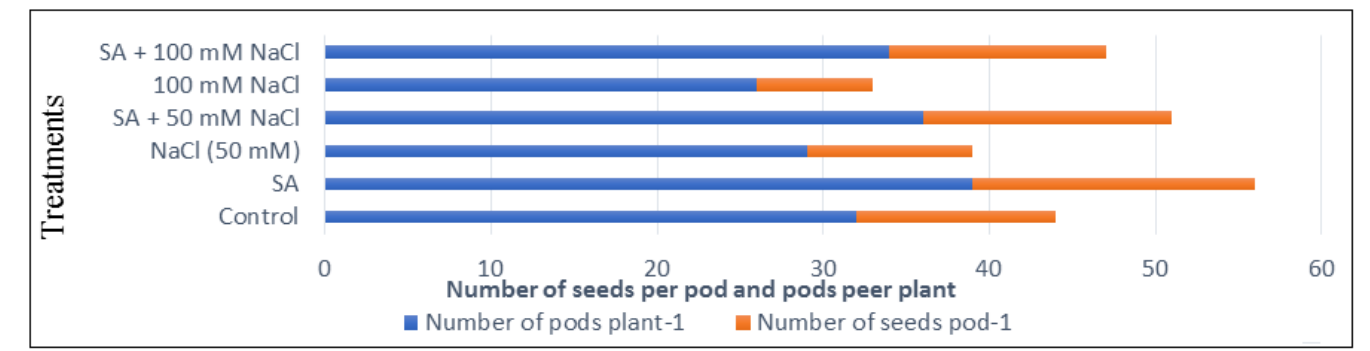

Graph-6: Effect of salicylic acid spray on Number of pods and seeds of fenugreek grown with graded levels of salinity

Environmental stress due to salinity is one of the most severe factors limiting the productivity of crops, most of which are sensitive to the presence of a high concentration of salts in the soil. Salt stress toxicity causes biological as well as physiological damage like seed germination, leaf area, premature senescence and decrease in chlorophyll content, leads to a subsequent reduction in dry mass of the plant. Both development and morphogenesis are highly sensitive to salt stress. Stressful environments induce the generation of reactive oxygen species (ROS), hydroxyl radical $(\mathrm{OH}-)$ etc. in plants thereby creating a state of oxidative stress which disturb the cellular redox system that may damage DNA, inactivate enzymes and cause lipid peroxidation. Thus, the present study was conducted on fenugreek (Trigonella foenum-graecum L.), to analyse the influence of salt stress on growth. The resultant plants from salt-treated seeds recorded lower values for all the growth attributing parameters. It was confirmed that $50 \mathrm{mM}$ and $100 \mathrm{mM}$ salt concentrations harm the growth, biochemical and yield parameters of fenugreek. Salt stress reduces plant height, fresh weight, dry weight, chlorophyll content, NR activity, pods and seed yield in fenugreek. The foliar application of SA alleviates the negative effect of salinity. This effect was more pronounced in $50 \mathrm{mM}$ salt stress than $100 \mathrm{mM}$ (graphs). The first plant part interacts with salt is the roots, but they trigger the avoidance mechanism hence less affected by salt stress as compared to shoot. Saltinduced reduction in growth and photosynthesis has been attributed to high $\mathrm{Na}^{+}$and $\mathrm{Cl}^{-}$, reduction in water potential, increase in osmotic potential, inhibition of photochemical processes, and the increased production of ROS in the chloroplast [28].
The ameliorative effect of SA application on growth parameters may be attributed to its role as in membrane integrity and regulation of ion uptake [41, 42]. The results agree with the findings of [43] working on fenugreek. Further, analysis of salt stress on physiological parameters revealed a positive correlation. Among all photosynthetic pigment's chlorophyll b is profoundly affected by salt stress. Foliar spray of SA has significantly counter-effect the salt stress in the biochemical parameters (Graphs). The harmful effects of salinity were further confirmed with a decrease in yield characteristics such as seed yield, pods number (Figures). To overcome these stresses, the exogenous application of salicylic acid plays a vital role intolerance as it functions as a defensive mechanism to revoke the exogenous salt stress. Treatment of plants with salicylic acid induces tolerance against salinity. Salicylic acid is known to affect various physiological and biochemical activities of plant and play a key role in regulating their growth and productivity.

\section{CONCLUSION}

It may be concise that salicylic acid affects plant growth and development and reduces the adverse effects of salt stress. SA is preferred against salinity because it is a good weapon that mitigates or copes with the damaging effects of salinity. It was detected that salicylic acid potentially generates a wide array of metabolic responses in plants and affects the photosynthetic parameters and plant water relationship. Exogenous application of salicylic acid enhances photosynthetic rate, stomatal conductance in fenugreek. It may be resolved from the above discussion that salicylic acid acts as a potent plant growth regulator that can effectively modulate various plant growth responses. 


\section{REFERENCES}

1. Ulbricht, C., Basch, E., Burke, D., Cheung, L., Ernst, E., Giese, N., ... \& Miranda, M. (2008). Fenugreek (Trigonella foenum-graecum L. Leguminosae): an evidence-based systematic review by the natural standard research collaboration. Journal of herbal pharmacotherapy, 7(3-4), 143-177.

2. Zhou, J., Chan, L., \& Zhou, S. (2012). Trigonelline: a plant alkaloid with therapeutic potential for diabetes and central nervous system disease. Current medicinal chemistry, 19(21), 3523-3531.

3. Hamza, N., Berke, B., Cheze, C., Le Garrec, R., Umar, A., Agli, A. N., ... \& Moore, N. (2012). Preventive and curative effect of Trigonella foenum-graecum $\mathrm{L}$. seeds in C57BL/6J models of type 2 diabetes induced by high-fat diet. Journal of ethnopharmacology, 142(2), 516-522.

4. Khan, M. A., Ungar, I. A., \& Showalter, A. M. (2000). Effects of salinity on growth, water relations and ion accumulation of the subtropical perennial halophyte, Atriplex griffithii var. stocksii. Annals of Botany, 85(2), 225-232.

5. Locy, R. D., Chang, C. C., Nielsen, B. L., \& Singh, N. K. (1996). Photosynthesis in saltadapted heterotrophic tobacco cells and regenerated plants. Plant physiology, 110(1), 321328.

6. Xiong, L., Schumaker, K. S., \& Zhu, J. K. (2002). Cell signaling during cold, drought, and salt stress. The plant cell, 14(suppl 1), S165-S183.

7. Shiyab, S. M., Shibli, R. A., \& Mohammad, M. M. (2003). Influence of sodium chloride salt stress on growth and nutrient acquisition of sour orange in vitro. Journal of Plant Nutrition, 26(5), 985-996.

8. Gossett, D. R., Banks, S. W., Millhollon, E. P., \& Lucas, M. C. (1996). Antioxidant response to $\mathrm{NaCl}$ stress in a control and an $\mathrm{NaCl}$-tolerant cotton cell line grown in the presence of paraquat, buthionine sulfoximine, and exogenous glutathione. Plant Physiology, 112(2), 803-809.

9. Cavalcanti, B. C., Costa-Lotufo, L. V., Moraes, M. O., Burbano, R. R., Silveira, E. R., Cunha, K. M. A., ... \& Pessoa, C. (2006). Genotoxicity evaluation of kaurenoic acid, a bioactive diterpenoid present in Copaiba oil. Food and chemical toxicology, 44(3), 388-392.

10. Lee, J. C., Lee, K. Y., Kim, J., Na, C. S., Jung, N. C., Chung, G. H., \& Jang, Y. S. (2004). Extract from Rhus verniciflua Stokes is capable of inhibiting the growth of human lymphoma cells. Food and Chemical Toxicology, 42(9), 1383-1388.

11. Ksouri, R., Megdiche, W., Debez, A., Falleh, H., Grignon, C., \& Abdelly, C. (2007). Salinity effects on polyphenol content and antioxidant activities in leaves of the halophyte Cakile maritima. Plant Physiology and Biochemistry, 45(3-4), 244-249.
12. Raskin, I., Skubatz, H., Tang, W., \& Meeuse, B. J. (2019). Salicylic Acid Levels in Thermogenic and Non- Thermogenic Plants Sign in Oxford Academic account Sign in via your Institution; 16.

13. Kang, H. M., \& Saltveit, M. E. (2002). Chilling tolerance of maize, cucumber and rice seedling leaves and roots are differentially affected by salicylic acid. Physiologia Plantarum, 115(4), 571-576.

14. Chini, A., Grant, J. J., Seki, M., Shinozaki, K., \& Loake, G. J. (2004). Drought tolerance established by enhanced expression of the CC-NBS-LRR gene, ADR1, requires salicylic acid, EDS1 and ABI1. The Plant Journal, 38(5), 810-822.

15. Janda, T., Szalai, G., Tari, I., \& Paldi, E. (1999). Hydroponic treatment with salicylic acid decreases the effects of chilling injury in maize (Zea mays L.) plants. Planta, 208(2), 175-180.

16. Metwally, A., Finkemeier, I., Georgi, M., \& Dietz, K. J. (2003). Salicylic acid alleviates the cadmium toxicity in barley seedlings. Plant physiology, 132(1), 272-281.

17. Malek, E., Davis, T., Martin, R. S., \& Silva, P. J. (2006). Meteorological and environmental aspects of one of the worst national air pollution episodes (January, 2004) in Logan, Cache Valley, Utah, USA. Atmospheric research, 79(2), 108-122.

18. Borsani, O., Valpuesta, V., \& Botella, M. A. (2001). Evidence for a role of salicylic acid in the oxidative damage generated by $\mathrm{NaCl}$ and osmotic stress in Arabidopsis seedlings. Plant physiology, 126(3), 1024-1030.

19. Fariduddin, Q., Hayat, S., \& Ahmad, A. (2003). Salicylic acid influences net photosynthetic rate, carboxylation efficiency, nitrate reductase activity, and seed yield in Brassica juncea. Photosynthetica, 41(2), 281-284.

20. Singh, B., \& Usha, K. (2003). Salicylic acid induced physiological and biochemical changes in wheat seedlings under water stress. Plant Growth Regulation, 39(2), 137-141.

21. ASHRAF, M. (2006). Effect of salicylic acid applied through rooting medium on drought tolerance of wheat. Pak. J. Bot, 38(4), 1127-1136.

22. Ashraf, M., Akram, N. A., Arteca, R. N., \& Foolad, M. R. (2010). The physiological, biochemical and molecular roles of brassinosteroids and salicylic acid in plant processes and salt tolerance. Critical Reviews in Plant Sciences, 29(3), 162-190.

23. Stevens, J., Senaratna, T., \& Sivasithamparam, K. (2006). Salicylic acid induces salinity tolerance in tomato (Lycopersicon esculentum cv. Roma): associated changes in gas exchange, water relations and membrane stabilisation. Plant Growth Regulation, 49(1), 77-83.

24. Nazar, R., Iqbal, N., Syeed, S., \& Khan, N. A. (2011). Salicylic acid alleviates decreases in photosynthesis under salt stress by enhancing 
nitrogen and sulfur assimilation and antioxidant metabolism differentially in two mungbean cultivars. Journal of Plant Physiology, 168(8), 807-815.

25. Szepesi, Á. (2008). Influence of exogenous salicylic acid on antioxidant enzyme activities in the roots of salt stressed tomato plants. Acta Biologica Szegediensis, 52(1), 199-200.

26. Ashraf, M. (2010). Inducing drought tolerance in plants: recent advances. Biotechnology advances, 28(1), 169-183.

27. Hayat, Q., Hayat, S., Irfan, M., \& Ahmad, A. (2010). Effect of exogenous salicylic acid under changing environment: a review. Environmental and experimental botany, 68(1), 14-25.

28. Gunes, A., Inal, A., Alpaslan, M., Cicek, N., Guneri, E., Eraslan, F., \& Guzelordu, T. (2005). Effects of exogenously applied salicylic acid on the induction of multiple stress tolerance and mineral nutrition in maize (Zea mays L.) (Einfluss einer Salicylsäure-Applikation auf die Induktion von Stresstoleranz sowie Nährstoffaufnahme von Mais [Zea mays L.]). Archives of Agronomy and Soil Science, 51(6), 687-695.

29. Yildirim, E., Turan, M., \& Guvenc, I. (2008). Effect of foliar salicylic acid applications on growth, chlorophyll, and mineral content of cucumber grown under salt stress. Journal of plant nutrition, 31(3), 593-612.

30. Karlidag, H., Yildirim, E., \& Turan, M. (2009). Salicylic acid ameliorates the adverse effect of salt stress on strawberry. Scientia Agricola, 66(2), 180-187.

31. Durner, J., \& Klessig, D. F. (1995). Inhibition of ascorbate peroxidase by salicylic acid and 2, 6dichloroisonicotinic acid, two inducers of plant defense responses. Proceedings of the National Academy of Sciences, 92(24), 11312-11316.

32. Slaymaker, D. H., Navarre, D. A., Clark, D., del Pozo, O., Martin, G. B., \& Klessig, D. F. (2002). The tobacco salicylic acid-binding protein 3 (SABP3) is the chloroplast carbonic anhydrase, which exhibits antioxidant activity and plays a role in the hypersensitive defense response. Proceedings of the National Academy of Sciences, 99(18), 11640-11645.

33. Petropoulos, G. A. (2002). Fenugreek (C) 2002.

34. Altuntaş, E., Özgöz, E., \& Taşer, Ö. F. (2005). Some physical properties of fenugreek (Trigonella foenum-graceum L.) seeds. Journal of food engineering, 71(1), 37-43.

35. Moradi, N., \& Moradi, K. (2013). Physiological and pharmaceutical effects of fenugreek (Trigonella foenum-graecum L.) as a multipurpose and valuable medicinal plant. Global journal of medicinal plant research, 1(2), 199-206.

36. Madar, Z., \& Stark, A. H. (2002). New legume sources as therapeutic agents. British Journal of Nutrition, 88(S3), 287-292.

37. Pasandi Pour, A., Farahbakhsh, H., \& Saffari, M. (2014). Response of Fenugreek plants to shortterm salinity stress in relation to lipid peroxidation, antioxidant activity and protein content. Ethno-Pharmaceutical Products, 1(1), 4552.

38. Wickliff, J. L., \& Aronoff, S. (1962). Quantitative measurement of leaf chlorophylls by spectrophotometry of their pheophytins in aqueous alcoholic extracts. Plant physiology, 37(5), 584.

39. Jaworski, E. G. (1971). Nitrate reductase assay in intact plant tissues. Biochemical and biophysical research communications, 43(6), 1274-1279.

40. Amare, T., Sharma, J. J., \& Zewdie, K. (2014). Effect of weed control methods on weeds and wheat (Triticum aestivum L.) yield. World journal of agricultural research, 1(2), 124-128.

41. El-Tayeb, M. A. (2005). Response of barley grains to the interactive e. ect of salinity and salicylic acid. Plant Growth Regulation, 45(3), 215-224.

42. Eraslan, F., Inal, A., Gunes, A., \& Alpaslan, M. (2007). Boron toxicity alters nitrate reductase activity, proline accumulation, membrane permeability, and mineral constituents of tomato and pepper plants. Journal of plant nutrition, 30(6), 981-994.

43. Mehrafarin, A., Qaderi, A., Rezazadeh, S. H., Naghdi Badi, H., Noormohammadi, G. H., \& Zand, E. S. K. A. N. D. A. R. (2010). Bioengineering of important secondary metabolites and metabolic pathways in fenugreek (Trigonella foenum-graecum L.). Journal of Medicinal Plants, 3(35), 1-18.

44. Arnon, D. I. (1946). Copper enzymes in isolated chloroplast aDd polyphetroloxidases in Beta wlgaris. Pla t Physiol, 24, 1-5.

45. Raskin, I. (1992). Role of salicylic acid in plants. Annual review of plant biology, 43(1), 439463. 